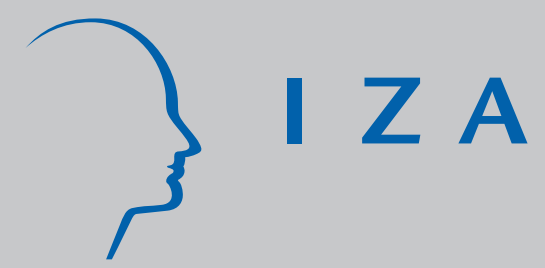

IZA DP No. 7616

Labor Market Institutions and the Response of Inflation to Macro Shocks in the EU: A Two-Sector Analysis

Gaetano D’Adamo

Riccardo Rovelli

September 2013

Forschungsinstitut zur Zukunft der Arbeit Institute for the Study of Labor 


\title{
Labor Market Institutions and the Response of Inflation to Macro Shocks in the EU: A Two-Sector Analysis
}

\author{
Gaetano D'Adamo \\ University of Valencia \\ Riccardo Rovelli \\ University of Bologna \\ and IZA
}

\section{Discussion Paper No. 7616 \\ September 2013}

IZA

P.O. Box 7240

53072 Bonn

Germany

\author{
Phone: +49-228-3894-0 \\ Fax: +49-228-3894-180 \\ E-mail: iza@iza.org
}

\begin{abstract}
Any opinions expressed here are those of the author(s) and not those of IZA. Research published in this series may include views on policy, but the institute itself takes no institutional policy positions. The IZA research network is committed to the IZA Guiding Principles of Research Integrity.

The Institute for the Study of Labor (IZA) in Bonn is a local and virtual international research center and a place of communication between science, politics and business. IZA is an independent nonprofit organization supported by Deutsche Post Foundation. The center is associated with the University of Bonn and offers a stimulating research environment through its international network, workshops and conferences, data service, project support, research visits and doctoral program. IZA engages in (i) original and internationally competitive research in all fields of labor economics, (ii) development of policy concepts, and (iii) dissemination of research results and concepts to the interested public.
\end{abstract}

IZA Discussion Papers often represent preliminary work and are circulated to encourage discussion. Citation of such a paper should account for its provisional character. A revised version may be available directly from the author. 
IZA Discussion Paper No. 7616

September 2013

\section{ABSTRACT \\ Labor Market Institutions and the Response of Inflation to Macro Shocks in the EU: A Two-Sector Analysis}

We model empirically the role of labor market institutions in affecting the response of inflation to labor market and exchange rate shocks in the EU. We adopt a simple Phillips curve framework, treating separately the sectors producing traded and non-traded goods. Our results show that labor market institutions have a significant role in affecting cross-country differences in inflation adjustment for the "sheltered" (non-trading) sector; the effects in the "exposed" (trading) sector are also significant but more limited. Increased wage coordination and more expenditure on LM policies (active or total) flatten the Phillips curve in both sectors. More active LM policies also reduce the persistence of inflation. However, but only in the non-trading sector, this effect is more than offset (in 15 countries out of 21) by the presence of stronger wage coordination, which increases the persistence of inflation. Finally, the adjustment of inflation to the real exchange rate, i.e. the exchange rate pass-through, is largely unaffected by institutional variables; only for non-tradables there is a strong negative effect of increased union density.

JEL Classification: $\quad$ E31, J50, J60

Keywords: labor market institutions, inflation determinants, two-sector models

Corresponding author:

Riccardo Rovelli

Department of Economics

University of Bologna

Strada Maggiore 45

40125 Bologna

Italy

E-mail: riccardo.rovelli@unibo.it 
IZA Discussion Paper No. 7616

September 2013

\section{NON-TECHNICAL SUMMARY}

How important are differences in labor market institutions for explaining the differences in the inflation rates within the EU countries?

We study the differences in the adjustment of inflation to macroeconomic shocks in the EU, for the period from 1994 until 2011. One peculiarity of our research is that we distinguish, for each country, between a more "sheltered" (non-trading) sector and one more "exposed" to international price competition (the trading sector). At the same time, we also take into account the different institutional characteristics of each country's labor market.

We find that some institutional characteristics increase the persistence of inflation (hence, they "slow down" the adjustment of labor markets to macro shocks), while others may reduce it, hence facilitating the adjustment to a new equilibrium: in particular, more expenditure on Active Labor Market Policies have the (welcome) effect of reducing the persistence of inflation, thus increasing its flexibility in the adjustment to macro shocks. This effect is especially evident in Denmark, Netherlands and Sweden, as well as in France and Poland. However for most countries (15 out of 21) this effect is more than offset (but only for the nontrading sector) by the presence of stronger wage coordination, which instead increases the persistence of inflation.

Also, we find that increased wage coordination and more expenditure on Labor Market Policies (active or total) flatten the Phillips curve in both sectors (but more strongly in the nontrading sector), that is they reduce the cyclical response of inflation to the unemployment cycle, thus weakening (for the good or the bad) one of the key inbuilt macroeconomic stabilizers of inflation. This implies that, where this is the case, inflationary discipline must then be maintained by other means than changes in the (un)employment rate. On the other hand, analyzing EU countries individually, we found that Estonia, Poland and the UK, followed by the Czech Republic, are the countries where inflation is more responsive to the unemployment cycle (the Phillips curve is steeper), and this is explained by the reduced importance of wage coordination mechanisms and also by the limited role of Active Labor Market (ALM) policies in these countries.

On the other hand we find that the adjustment of inflation to the real exchange rate, i.e. the exchange rate pass-through, is largely unaffected by institutional variables; this is especially true for the traded goods - confirming that prices in this sector are largely determined on the basis of international competitive pressures - and that local institutions do not undermine this competitive pricing. Only for non-tradables there is a strong negative effect of increased union density in reducing the pass-through - but this effect does not directly damage a country's competitiveness, as it is confined to the non-trading sector.

In general these findings also suggest that it is very important, from both a positive and a normative viewpoint, to take into account the complementary effects of different labor market institutions in affecting the relations between the labor market and the macroeconomic cycle. 


\section{Introduction}

Modern versions of the Phillips curve describe the key relation between unemployment and inflation in most macro models. Within this broad framework, a wide array of theoretical models and empirical works show how inflation may be further affected by various macroeconomic shocks such as oil price shocks, indirect taxes, international price and exchange rate shocks, and so on. ${ }^{1}$

Empirical estimates of the inflationary impact of different types of shocks vary a lot across countries, and also across different sectors within the same country. These differences are influenced, among other things, by the degree of openness of the economy and by the tradability of specific goods and services: in a small open economy we expect prices of traded goods (more precisely, the prices of goods and services produced in sectors more exposed to foreign price competition) to be internationally determined, while the prices of non-traded goods or services (which are produced in the more sheltered sectors) may be also affected by domestic factors. Indeed, an empirical stylized fact is that the inflation rate measured for the non-trading sector is higher than that measured for the trading sector. A reason for this, according to the Scandinavian model of inflation (Aukrust 1970 ) is that labor productivity grows faster in the trading sector; as wages increase there, due to free labor mobility across sectors, firms in the sector producing non-tradable good or services will have to raise wages as well, and compensate wage increases with higher prices. $^{2}$

In addition, while relative inflation is generally higher in the non-trading sector, the two are not perfectly correlated, which may reflect the fact that they respond with different speed and intensity prices to the same macro shocks. Figure 1 shows the evolution of both measures of inflation in the EU-27 between 1994 and 2010. The average correlation between the two series is 0.82 , but inflation is often higher in the non-trading sector, with few exceptions especially in the more recent years. $^{3}$

\section{[insert Figure 1 here]}

\footnotetext{
${ }^{1}$ See Svensson (1997 and 2000), Gali and Monacelli (2005), Bowdler and Nunziata (2007), Biroli et al. (2010).

${ }^{2}$ In the original formulation of the Scandinavian model wages are set exogenously. However, as Paunio and Halttunen (1976) observe, "there is an implicit 'theory' about the determination of wages: productivity changes in the exposed industries and world market prices determine them if the exchange rate is fixed". This in fact is the same mechanism which may be used to rationalize the Balassa-Samuelson effect in catching up economies (see Section 2 below).

${ }^{3}$ Since 1997, the average annual inflation rate for tradables in the EU 27 has been 1,9\%, while that for non-tradables $2,7 \%$, but the standard deviation of the former is more than double relative to the latter. The higher cyclical volatility of tradables inflation was especially relevant in the recession year 2009.
} 
Identifying the determinants of sectoral inflation and how institutions affect its responsiveness to macroeconomic shocks is a policy relevant question, especially as prices in the trading sector are direct determinants of a country's competitiveness. Many policy analysts have been stressing the importance of increasing labor market flexibility to restore the competitiveness of EMU countries which have accumulated large international imbalances: since EMU countries do not have the possibility of using the exchange rate to correct disequilibria, all the adjustment has to be made via internal devaluation.

In this paper we study from an empirical point of view the effect of labor market institutions on the way inflation responds to macroeconomic shocks, considering the trading and non-trading sectors separately. Therefore, we focus on whether and to what extent some characteristics of the labor market (in particular, union density, the degree of coordination in wage bargaining and some measures of labor market policy expenditure) tend to amplify or curb the transmission of macroeconomic shocks to prices. To that end, we follow the approach set by Nunziata and Bowdler (2007) to estimate a simple reduced-form equation for inflation (a Phillips curve), adding interactions between macroeconomic variables and labor market institutional indicators as explanatory variables, and we apply this approach separately for the price indexes of traded and non-traded goods.

Our results show that there are important differences in inflation adjustment across countries, and these differences are due to labor market institutions. Stronger or more rigid labor market institutions tend to reduce the adjustment to macroeconomic variables and to increase inflation persistence. However this effect is not the same for the trading versus non-trading sectors, as labor market institutions affect to a larger extent the latter, which is also the more responsive to the unemployment cycle.

The paper is structured as follows: Section 2 reviews the literature on the topic; Section 3 introduces the dataset and the empirical model. In Section 4 we report the empirical results. Section 5 concludes.

\section{Literature review}

There is a wide theoretical and empirical macroeconomic literature on inflation determination. Since Phillips (1958) and then following the critiques and reformulations of Phelps (1967) and Friedman (1968), research on the issue has generally modeled inflation as being determined by the economic cycle (i.e. the deviation of unemployment from the long-run level or the output gap); inflation expectations, generally modeled as a weighted average of past inflation and other inflation indicators; the exchange rate and/or imported inflation, for a small open 
economy; and some variable representing the government's fiscal policy (for example, indirect taxes and/or the public deficit to GDP ratio) ${ }^{4}$.

One issue that has been investigated in specific reference to the Euro Area is the reason for the persistence of inflation differentials within the same currency area. A large part of these differentials can be explained as a consequence of price level convergence between countries with different levels of income per capita (as suggested by the Penn effect), and also by movements in the effective exchange rate and by business cycle. ${ }^{5}$

Other researchers have pointed out the role of labor and of product market institutions in affecting price formation and, possibly, also inflation. While labor market institutions may have an impact on price formation by affecting the marginal cost of labor and also by imposing transaction costs on the hiring and firing of labor6, this does not in general help to explain persistent changes in the inflation rate. Similarly, product market regulations may strengthen the market power of firms and, as a result, allow for higher mark-ups and thus for higher prices, but again this does not generally have direct implications for the evolution of inflation over time.

However, a different brand of literature has taken a more subtle approach towards suggesting a possible link between labor market institutions and inflation. This parallels the earlier approach of Blanchard and Wolfers (2000), who showed that, while neither macro shocks nor institutions per se can explain the persistence of high unemployment through time, it is really the interactions of shocks and institutions that lead to a larger and more persistent effect of shocks on unemployment. In a similar spirit, Andres et al. (2008), in a two-country model which is calibrated to mimic large euro area countries, show that inflation reacts faster to macroeconomic shocks in countries where markets are more competitive. Along this line, Bowdler and Nunziata (2007) and Jaumotte and Morsy (2012) use a traditional backward-looking Phillips curve framework to estimate the effect of labor and product market institutions on the reaction of inflation to different types of shocks. In both cases, the evidence is that more rigid labor market structures weaken the responsiveness of inflation to macro unemployment shocks and also to changes in the import prices or the exchange rate.

\footnotetext{
${ }^{4}$ See, among others, Svensson (1997 and 2000) and Gali and Monacelli (2005)

${ }^{5}$ See Stavrev (2007) and Angeloni and Ehrmann (2007).

${ }^{6}$ For instance, Nunziata (2005) shows that stricter employment protection, higher union density and higher unemployment benefits are associated with a higher aggregate wage, while coordination in wage bargaining has a significant negative effect on wages. Also Layard et al. (1991) and Nickell et al. (2005) show that, by allowing wages to be set at a higher level than the market-clearing one, stricter labor market institutions reduce labor demand and therefore are associated with higher unemployment.
} 
In this paper, we also focus on the interactions between labor market institutions and macro shocks in explaining inflation persistence (with the modifications that we discuss below). Instead, we neglect the role that might be played by product market regulations, for essentially two reasons. First, product market regulations (PMR) are predominantly related to the services sector. Second, introducing PMR measures alongside measures of labor market institutions creates serious problems of multicollinearity within our model, ${ }^{7}$ and this makes it difficult to disentangle empirically the effects of the two types of regulations. ${ }^{8}$

Our approach to modeling the inflationary impact of the interactions between shocks and institutions differs from that pursued so far in the literature, as we maintain throughout the analysis a distinction between sectors producing traded vs. non-traded goods and services. This distinction is necessary to assess the relevance of Balassa-Samuelson (B-S) effects to explain the different competitive performance of EU countries. The B-S hypothesis states that countries which are in the process of catching up experience real exchange rate appreciation; this is due to the fact that productivity grows faster in the tradable goods sector than in the non-tradable sector, thus pushing up wages in the former. Moreover, inter-sectoral labor mobility ensures wage equalization across domestic macro sectors, so that wages in the non-tradable sector increase in parallel: this pushes up the prices in the non-trading sector, which ultimately causes the increase in the CPI that determines real appreciation. The literature that focused on convergence in the last decade has been using alternative approaches to measure the importance of the B-S effect but, broadly speaking, the main result seems to be that such effect can account only for a minor part of the excess inflation observed in Central and Eastern European Countries (CEEC; see Egert 2007). These results suggest that other factors may indeed be at play $^{9}$, and in these paper we wish to explore the possible role of labor market institutions in this respect.

\footnotetext{
7 Results of the models estimated in Section 4 including PMR measures are available from the authors upon request. The correlation between PMR and Labor Market Regulation measures interacted with the macroeconomic variables is always above 0.80 .

8 This problem is compounded by the fact that the OECD index of economy-wide PMR is available only for 3 years, making an econometric analysis unfeasible for the group of countries we are interested in, while the annual index of PMR available from the OECD is mostly representative of services, as it refers to airlines, telecoms, electricity, gas, post, rail, and road freight, and is not available until 2007 for Slovenia and Estonia, and until 2002 for Slovakia.

${ }^{9}$ One effect that has been suggested in particular is related to Engel's law, which postulates that, during the catching up process, consumers move to higher-quality goods, thus indirectly pushing up the observed CPI (Égert and Podpiera 2008 and Egert 2010).
} 


\section{Data and econometric methodology}

We use annual data from 1994 until 2010 for the EU 27 countries. The shortness of the sample is due to the availability of price series for traded and non-traded goods for some of the countries, in particular Germany. We actually consider two alternative samples: the EU 27 and the EU 21, i.e. the member States of the E.U. which are also in the OECD, in order to extend the analysis to some institutional variables which are only available for OECD countries. This latter sample excludes Latvia, Lithuania, Cyprus, Malta, Romania and Bulgaria.

Following a practice which is common in the empirical literature ${ }^{10}$, we approximately identify the trading sector with the production of goods and the non-trading sector with that of services. This choice of proxy is of course objectionable, on the twin grounds that not all goods (not even all manufactured goods) are in fact tradable while an increasing number of services is, and that the distinction between services and manufacturing is by itself imprecise. ${ }^{11}$ However, it is almost impossible - to our knowledge - to achieve a more precise identification of the tradable potential of each sector's production, and thus we stay with the distinction which has been traditionally maintained in the literature. In its defense, we can observe that, even if the distinction between tradables and non-tradables does not coincide with that between goods and services, nevertheless in general the tradable potential of goods is considerably higher than that of services.

Data on labor market institutions come from the OECD and the ICTWSS database. ${ }^{12}$

The inflation equation that we estimate, separately for the trading and non-trading sectors, is the following:

$$
\text { inf }_{i j, t}=\alpha_{i j}+\delta_{i j}+\boldsymbol{\beta}_{j}^{\prime} \boldsymbol{X}_{i, t}+\boldsymbol{\gamma}_{j} \boldsymbol{Z}_{i, t} * \boldsymbol{X}_{i, t}+\varepsilon_{i j, t}
$$

where $j=N, T$ refers to non-trading and trading sectors respectively and $i=1, \ldots, 27$ are the countries. $\alpha$ are country fixed effects and $\delta$ represents year dummies. $X$ is a vector of "macroeconomic variables", and $Z$ is a vector of "institutional variables". The macroeconomic variables included are: lagged sectoral inflation $\left(i n f_{i j, t-1}\right)$, taken as a (naive) proxy of inflation expectations and as a measure of inflation persistence, the deviation of the unemployment from its

\footnotetext{
10 See Mihaljek and Klau (2004) for a review.

${ }^{11}$ See Christensen (2013), who concludes that "The increasing complexity of production, inertia in changes to statistical systems and the increasing integration of manufacturing products and services are some of the primary and interrelated explanations for this lack of precision". In addition, as Nordas and Kim (2013) observe, the competitiveness of services in also a key ingredient for manufacturing competitiveness.

12 Detailed definitions of all the variables and sources are reported in the Data Appendix.
} 
long-run trend (ucycle) $)^{13}$, and the real effective exchange rate (REER). ${ }^{14}$ To avoid endogeneity problems, and because the exchange rate may affect inflation with some lag, REER is lagged one year. This is also consistent with the fact that changes in international prices may affect domestic prices with some delay. ${ }^{15}$

The institutional or policy variables that we include are: Union Density $(U D)$, which measures the share of employed who are members of a union, Wage Coordination $(W C O O R)$, which measures the degree of coordination in wage bargaining, Unemployment Benefits as a share of GDP $(U B E N)$, and expenditures on Active ( $\left.L M P_{-} A C T\right)$ or Total Labor Market Policies (LMP_TOT), also measured as a share of GDP. ${ }^{16}$

To interpret the regression results, note that the $\gamma$ coefficients in eq. (1) measure the marginal effect of labor market institutions on the adjustment of inflation to, respectively, its lagged value, the unemployment rate and the real exchange rate. These marginal effects will therefore be varying across countries and through time following the different characteristics of labor market institutions and their evolution in time. Thus, the marginal effect of any macroeconomic variable, say ucycle, for country $i$ in sector $j$ at time $t$, will be given by the sum of two components:

$$
\beta_{j} X_{i, t}+\gamma_{j} Z_{i, t} X_{i, t}
$$

where $X_{i, t}=\operatorname{ucycle}(i, t)$.

\footnotetext{
13 The unemployment trend has been removed with an HP filter. As a robustness check, we also estimated the base model filtering the unemployment rate with a moving average, but the results were unaltered.

14 Panel unit root tests confirm that all macroeconomic variables are I(0).

15 In a preliminary analysis, the following macroeconomic variables were also included: growth rate of labor productivity (measured as gross value added per person), percentage change in the indirect tax wedge, and imported inflation. However, none come out to be significant. The finding that productivity growth does not impact (negatively) on inflation suggests that all productivity gains are transferred to the factors of production, via higher profits or wages. Also note that a better measure of productivity growth would have been the rate of change of gross value added per hour worked; however using this measure would have seriously reduced our sample in both the time and space dimensions.

16 The degree of Employment Protection $(E P L)$ and the Minimum Wage Ratio, as measured by the OECD were also included in a preliminary analysis but never came out to be significant, confirming the finding (for EPL) of Nunziata and Bowdler (2007). Centralization in wage bargaining (CENT in the ICTWSS database) was also excluded, due to serious problems of multicollinearity.
} 


\section{Facts and findings}

We observed from Figure 1 that inflation in the non-trading sector has generally been higher than for traded goods. In more detail, Table 1a reports the means of some key variables in our analysis for three periods, and Table $1 \mathrm{~b}$ for each country. The three periods we consider are before adoption of the euro (1994-1998), the euro period until the crisis (1999-2007) and the years of the great recession (2008-2011).

\section{[insert Tables 1a, 1b here]}

Looking at Table 1a, we observe that: (i) inflation for both traded and non-traded goods has been declining through the three periods, and also the difference between the two has narrowed; (ii) inflation in both sectors has become less persistent, as measured by the correlation with the previous year inflation; (iii) the structure of labor markets has become more flexible: union density has declined (a pattern which has been documented for many countries also outside the EU, see Riley 1997) and wage setting is less coordinated.

Focusing on individual countries (Table 1b) we can broadly identify some groupings: the Nordic countries, with high coordination and union density as well as high active LMP, but low inflation; the Central and Eastern European Countries (CEEC), with higher inflation, presumably due to ongoing (output and price level) convergence, medium-low union density and wage coordination and low expenditure on LMP; the Euro Area periphery (the so called "PIIGS") with mediumlow union density, below 40\%, high wage coordination and low expenditure especially on active LMP.

To model these facts with a regression model, our strategy is first to estimate a simple backward-looking Phillips curve (the "base inflation equation"), which only includes the macro explanatory variables (vector $X$ in equation 1 ). Then, we estimate the complete models with interactions, and finally we obtain simplified specifications for the "preferred" models, using a general to specific strategy.

\section{[insert Table 2 here]}

Table 2 reports the results of the estimation of the base inflation equation for the EU-27 and the EU-21, including country fixed effects and year dummies. All macro variables are strongly significant and signed according to our expectations. The estimates in both samples confirm that inflation is more persistent in the nontrading sector. The impact effect of an increase of the unemployment rate by $1 \%$ above trend causes inflation (in both sectors) to fall by $0.24 \%$, and that of a $1 \%$ real depreciation (a fall in REER) increases inflation by $0.1 \%$.

In the next stage, we add to these base regressions, the interactions between the macro and the institutional variables (vector $Z$ in equation 1), to study how the 
responsiveness of inflation is affected by different labor market institutions. The results are reported in Table 3 (for the EU-21 sample) and Table 4 (EU-27).

\section{[insert Tables 3, 4 here]}

First, we notice that labor market institutions have a more significant impact on inflation in the non-trading sector. This can be seen by comparing the upper and lower panel of Table 3, and the left versus right columns in Table 4, and noting that the number and absolute values of the estimated significant coefficients of the interaction terms are much larger for the non-trading sector (resp. the lower panel in Table 3, and the right columns in Table 4).

Second, a more coordinated labor market is characterized by weaker responsiveness of inflation to macroeconomic variables. Higher wage coordination reduces the responsiveness of inflation to unemployment, flattening the Phillips curve. The same occurs with higher labor market policy expenditure or unemployment benefits, but the results are only significant for the non-trading sector. Larger union membership is associated with lower pass-through from the exchange rate in the non-trading sector (Table 4). Also the persistence of inflation may be affected by institutional factors: we find that an increase in expenditures on active labor market policies reduces the persistence of inflation and thus also reduces the overall effect of macroeconomic shocks on inflation, for both sectors.

In general, the results in Table 4 are very close to those in Table 3 , but estimates seem to be more precise. However, since the variables LMP_TOT and LMP_ACT are not available for all 27 EU countries, the equation models 2-5 and 7 from Table 3 cannot be estimated for this larger sample.

As a final step, we selected (on the basis of the standard error of the regressions) the preferred models from Tables 3 and 4, and we simplified the specification using a general-to-specific approach, restricting to zero all the coefficients which were less than $10 \%$ significant. The results of this procedure are shown in Table $5 .{ }^{17}$ They confirm that stronger wage coordination increases inflation persistence (column $\mathrm{N} 4$, for the non-trading sector) and reduces the impact on inflation of the business cycle for both sectors (columns T4, T6 and N4, N5, N6, respectively), although the effects are stronger for the non-trading sector. In particular, when $W C O O R$ is at its maximum level $(W C O O R=5)$, the Phillips curve becomes practically flat (columns T4, T6 and N4, N5, N6). Union density drastically reduces the adjustment of inflation to real exchange rate shocks only in the non-trading sector (columns N4, N5, N6). The more efficient estimates presented in Table 5 also generate one important difference with respect to the results presented in Table 3, as they reveal that more expenditure on Total LMP does significantly flatten the Phillips curve also for the trading sector (columns T5 and T7), although

\footnotetext{
17 The last row of Table 5 also reports the result of the LR test on all restrictions imposed.
} 
this effect is much smaller than for the non-trading sector (columns N4 for Active LMP, and N5 for Total).

\section{[Insert Table 5 here]}

A different way to look at these results is to compute how they explain the different patterns of inflation adjustment in the different countries. For this purpose, in the different panels of Figure 2 we show graphically, for each country, the estimated point values of inflation persistence and of its response to unemployment and real exchange rate shocks, for each one of the EU-21 countries. The coefficients are calculated as in equation (2), where the $\beta$ and the $\gamma$ for inflation in the trading and non-trading sectors are taken from the estimates in columns T4 and N4 of Table 5, respectively. ${ }^{18}$ In each panel of Figure 2, we show for each country the estimated adjustment coefficient (the same for all countries), the idiosyncratic effect(s)s of the institutional variable(s) included in the estimated equation and the compounded overall effect, obtained as the sum of the previous two effects.

\section{[Insert Figure 2 here]}

The results are quite suggestive. First, we observe that active labor market policies reduce the persistence of inflation in both sectors (Panels $a$ and $b$ in Figure 2). However, for non-trading sector this effect is more than offset (in 15 countries out of 21) by the presence of stronger wage coordination, which on the contrary increases the persistence of inflation. The countries where the effect of active policies in reducing persistence (and thus, in facilitating the inflation adjustment to the business cycle) prevails are three Nordic countries (DK, NL, SE) plus France and Poland. In the UK, the two institutional effects are perfectly balanced.

As we observed before, both WCOOR and $L M P_{-} A C T$ tend to curb the reaction of inflation to unemployment. In panels $c$ and $d$ of Figure 2 we observe that WCOOR flattens the Phillips curve in most countries. For traded goods this effect is minimal only for Estonia, Poland and the UK, whereas for non-trading sector this effect is reinforced by the presence of active labor market policies, although still Estonia Poland and the UK, followed by the Czech Republic, remain the countries where inflation is more responsive to unemployment also in the non-trading sector. On the contrary, the Phillips curve is almost flat for the trading sector in many continental countries (Austria, Belgium, Germany), Nordic (Denmark, Finland, Netherland) and Mediterranean countries (Spain, Greece, Italy) plus Ireland and Slovenia and, for the non-trading sector, for the same countries plus Sweden and minus Slovenia.

\footnotetext{
18 These two models have been selected on the basis of the standard error of the regression.
} 
On the other hand, as panels $e$ and $f$ show, cross country differences are very much reduced in the case of inflation response to the REER, suggesting that the exchange rate pass-through in traded goods is strikingly similar across countries, which makes sense in the case of small open economies, where the prices of traded goods are internationally determined. In the non-trading sector there is a smoothing effect of union density on the exchange rate pass-through, but this is mostly quite limited, except for Denmark, Finland and Sweden.

To conclude, we note that - among the several directions in which our analysis could be continued - it would be useful to integrate in our framework the interactions between price formation in the trading and non-trading sectors, as we expect that these interactions may be stronger in countries with more extensive wage coordination and union density. This study would however require a more disaggregate dataset, both in the space and time dimensions.

\section{Conclusions}

In this paper we have analyzed how labor market institutions may affect the adjustment of inflation to macroeconomic events, assuming that the adjustment may be different for the prices of traded and non-traded goods or services. Previous authors (Nunziata and Bowdler 2005) had shown that, in general, more rigid labor market institutions tend to curb inflation adjustment to movements in macroeconomic variables. We analyzed inflation in the trading and non-trading sectors separately, because the two sectors face different competitive pressures, and at the same time price developments in each sector have very different implications for the external competitiveness of an economy.

Our results show that, within a simple augmented Phillips curve framework, inflation for non-tradables is more persistent than for tradables. We then introduced in the empirical analysis also the interactions with labor market institutions. Overall, institutions affect to a larger extent the adjustment of inflation in the non-trading sector, while the effect in the trading sector is more limited. This confirms the basic hypothesis that, for small open economies, domestic factors are less relevant in determining the evolution of prices of traded goods. However, we do find also some institutional effects which are relevant and common to both sectors: increased wage coordination and more expenditure on LM policies (active or total) do flatten the Phillips curve in both cases, while ALM policies reduce the persistence of inflation. On the other hand, but only for the non-trading sector, we also find that more wage coordination increases inflation persistence (thus, for this sector, going against the effect of ALM policies, which tend to reduce it).

These results imply that different labor market institutions and policies may also contribute to explain important cross-country differences. Analyzing EU countries individually, we have found that Estonia, Poland and the UK, followed by the Czech 
Republic, are the countries where inflation is more responsive to the unemployment cycle, and this is explained by the reduced importance of wage coordination mechanisms and also (especially for the non-trading sector) by the limited role of ALM policies in these countries. On the other hand, somewhat to the contrary, ALM policies reduce the persistence of inflation, and hence increase its flexibility in the adjustment to macro shocks. This effect is especially evident in Denmark, Netherlands and Sweden, as well as in France and Poland. We noted instead that, for a majority of countries (15 out of 21) this effect is more than offset, but only for non-traded goods, by the presence of stronger wage coordination, which on the contrary increases the persistence of inflation.

These observations also imply that it is very important, from both a positive and a normative viewpoint, to take into account the complementary effects of different labor market institutions in affecting the relations between the labor market and the macroeconomic cycle.

\section{Acknowledgements}

Gaetano D'Adamo acknowledges the financing support from Spanish MICINN (ECO2011-30260-CO3-01).

\section{References}

Angeloni, I., and Ehrmann, M. (2007) "Euro area inflation differentials". The B.E. Journal of Macroeconomics 7 (1), Article 24.

Andrés, J., Ortega, E., and Vallés, J. (2008) "Competition and inflation differentials in EMU”. Journal of Economic Dynamics and Control 32 (3), pp. 848-874.

Aukrust, 0. (1970) "PRIM 1: A model of the price and income distribution mechanism of an open economy". The Review of Income and Wealth 16 (1), pp. 51-78.

Baltagi, B. (1995) Econometric analysis of Panel Data, New York: Wiley.

Blanchard, O., and Wolfers, J. (2000) "The role of shocks and institutions in the rise of european unemployment: the aggregate evidence". The Economic Journal 110, C1-C33.

Bowdler, C. and Nunziata, L. (2007) "Inflation adjustment and labour market structures: evidence from a multi-country study". Scandinavian Journal of Economics, Wiley Blackwell 109(3), pp. 619-642. 
Christensen, J.L. (2013) "The ability of current statistical classifications to separate services and manufacturing". Structural Change and Economic Dynamics 26, pp. 47-60.

Egert, B. (2007) "Real convergence, price level convergence and inflation in Europe". Bruegel Working Paper $\mathrm{N}^{\circ} 2007 / 02$.

Egert, B. (2010) “Catching up and inflation in Europe: Balassa-Samuelson, Engel's Law and other culprits". OECD Economics Department Working Paper $\mathrm{N}^{\circ} 792$, OECD Publishing.

Egert, B., and Podpiera, J. (2008) "Structural inflation and real exchange rate appreciation in Visegrad-4 countries: Balassa-Samuelson or something else?" CEPR Policy Insight No. 20, London: CEPR.

Friedman, M. (1968) "The role of monetary policy." American Economic Review 58 (1), pp. 1-17.

Gali, J. and Monacelli, T. (2005) "Monetary policy and exchange rate volatility in a small open economy", Review of Economic Studies 72, pp. 707 - 734.

Jaumotte, F. and H. Morsy (2012) "Determinants of inflation in the Euro Area: the role of labor and product market institutions", IMF Working Paper WP/12/37.

Layard, R., Nickell, J. S. and R. Jackman (1991). Unemployment: Macroeconomic Performance and the Labour Market, Oxford: Oxford University Press.

Mihaljek, D. and M. Klau. 2004. "The Balassa-Samuelson effect in Central Europe: a disaggregated analysis". Comparative Economic Studies, 46(1), pp. 63-94.

Nickell, S.J. (1998) "Unemployment: questions and some answers". The Economic Journal 108, pp. 802-816.

Nickell, S., Nunziata, L., and Ochel, W. (2005) "Unemployment in the OECD since the 1960s. What do we know?" The Economic Journal, 115, pp. 1-27.

Norda, H.K., and Kim, Y. (2013) "The role of services for competitiveness in manufacturing”. OECD Trade Policy Papers No. 148, OECD Publishing.

Nunziata, L. (2005) "Institutions and wage determination: a multi-country approach". Oxford Bulletin of Economics and Statistics 67: 435-466.

Paunio, J.J., and Halttunen, H. (1976) "The 'Nordic' approach to inflation: interpretation and comments". In: M. Parkin and G.Zis (eds.) Inflation in the world economy. Manchester: Manchester U.P., pp. 259-272.

Phelps, E.S. (1967) "Phillips curves, expectations of inflation and optimal employment over time." Economica 34 (3), pp. 254-281.

Phillips, A. W. (1958). "The relationship between unemployment and the rate of change of money wages in the United Kingdom 1861-1957". Economica 25 (100), pp. 283-299. 
Riley, N.M. (1997) "Determinants of union membership: a review”. Labour 11 (2), pp. 265-301.

Stavrev, E. (2007) "Growth and inflation dispersions in EMU: reasons, the role of adjustment channels, and policy implications". IMF Working Papers 07/167, International Monetary Fund.

Svensson, L.E.O. (1997) "Inflation forecast targeting: implementing and monitoring inflation targets”. European Economic Review 41, pp. 111 - 1146.

Svensson, L.E.O. (2000) “Open-economy inflation targeting”, Journal of International Economics 50, pp. 155-183.

Visser, J. (2011) "Database on institutional characteristics of trade unions, wage setting, state intervention and social pacts, 1960-2010 (ICTWSS)". Downloaded from: http://www.uva-aias.net/208.

\section{Data Appendix}

\begin{tabular}{cl} 
Variable & Definition and Source \\
\hline infl $_{T}$ & Annual \% change in the HCPI for Goods. Source: Eurostat. \\
infl & Annual \% change in the HCPI for Services. Source: Eurostat. \\
ucycle & Unemployment rate, de-trended with HP filter. Source: Eurostat. \\
$R E E R$ & Real Effective Exchange Rate. Source: International Financial \\
& Statistics, IMF. \\
UD; & Union Density; Wage Coordination. \\
WCOOR & Source: ICTWSS Database, http://www.uva-aias.net/208. \\
UBEN & Unemployment Benefits, \% of GDP. Source: Eurostat. \\
LMP_ACT & Expenditure on active or total labor market policies, \% of GDP. \\
LMP_TOT & Source: OECD.
\end{tabular}


Table 1a. Summary statistics by period

\begin{tabular}{|c|c|c|c|}
\hline Period & 1994-1998 & 1999-2007 & $2008-2010$ \\
\hline $\operatorname{mean}\left(i n f l_{T}\right)$ & 3.45 & 2.81 & 2.70 \\
\hline $\operatorname{mean}\left(\right.$ inf $\left.l_{N}\right)$ & 6.49 & 4.13 & 3.23 \\
\hline$\sigma\left(i n f l_{T}\right)$ & 4.63 & 2.78 & 3.23 \\
\hline$\sigma\left(\operatorname{infl}_{N}\right)$ & 7.27 & 2.98 & 2.89 \\
\hline$\rho\left(\operatorname{infl}_{T, t}, \inf l_{T, t-1}\right)$ & 0.86 & 0.75 & 0.17 \\
\hline$\rho\left(\inf l_{N, t}\right.$, infl $\left.l_{N, t-1}\right)$ & 0.96 & 0.82 & 0.55 \\
\hline$\rho\left(\right.$ infl $_{T, t}$, infl $\left.l_{N, t}\right)$ & 0.95 & 0.82 & 0.79 \\
\hline$U D$ & 41.77 & 34.30 & 31.36 \\
\hline WCOOR & 2.79 & 2.72 & 2.56 \\
\hline$L M P \_A C T$ & 0.869 & 0.754 & 0,736 \\
\hline LMP_TOT & 2.595 & 1.909 & 1.921 \\
\hline$U B E N$ & 1.13 & 0.678 & 0.745 \\
\hline
\end{tabular}

Note: Average values across 27 countries ( 21 for LMP_ACT and LMP_TOT) for each sub-period. See Data Appendix for definition of variables. $\sigma()=$. standard deviation; $\rho()=$. correlation. 
Table 1b. Summary statistics by country

\begin{tabular}{|c|c|c|c|c|c|c|c|c|c|}
\hline & $\operatorname{infl} l_{T}$ & $\inf l_{N}$ & $\rho\left(\inf l_{T, t}, \inf l_{T, t-1}\right)$ & $\rho\left(\inf l_{N, t}, \inf l_{N, t-1}\right)$ & UD & WCOOR & LMP_ACT & LMP_TOT & UBEN \\
\hline Austria & 1.23 & 2.24 & -0.08 & 0.61 & 34.5 & 4 & 0.591 & 1.883 & 0.779 \\
\hline Belgium & 1.78 & 2.11 & -0.41 & -0.12 & 52.7 & 4.38 & 1.176 & 3.604 & 1.793 \\
\hline Bulgaria & 5.80 & 6.71 & -0.12 & 0.19 & 26.6 & 2.12 & - & - & 0.241 \\
\hline Cyprus & 2.32 & 2.93 & -0.65 & 0.03 & 63.4 & 2 & - & - & 0.393 \\
\hline Czech Rep. & 4.05 & 7.37 & 0.74 & 0.86 & 26.0 & 2 & 0.21 & 0.427 & 0.222 \\
\hline Denmark & 1.50 & 2.91 & -0.34 & 0.29 & 73.1 & 3.31 & 1.68 & 4.664 & 1.922 \\
\hline Estonia & 6.55 & 10.29 & 0.55 & 0.93 & 14.1 & 1 & 0.11 & 0.498 & 0.206 \\
\hline Finland & 1.02 & 2.52 & -0.11 & 0.53 & 74.0 & 3.63 & 1.03 & 3.586 & 2.067 \\
\hline France & 1.43 & 2.07 & -0.41 & 0.68 & 8.0 & 2 & 1.08 & 2.560 & 1.360 \\
\hline Germany & 1.37 & 1.58 & 0.09 & 0.34 & 23.2 & 4 & 1.08 & 3.06 & 1.146 \\
\hline Greece & 3.70 & 5.02 & 0.41 & 0.94 & 26.5 & 4 & 0.36 & 0.668 & 0.384 \\
\hline Hungary & 4.92 & 5.92 & -0.03 & 0.31 & 24.4 & 2 & 0.39 & 1.168 & 0.293 \\
\hline Ireland & 1.44 & 3.76 & 0.37 & 0.76 & 40.8 & 4.63 & 0.89 & 2.676 & 1.284 \\
\hline Italy & 2.29 & 2.87 & 0.28 & 0.80 & 34.8 & 4 & 0.51 & 1.447 & 0.320 \\
\hline Latvia & 4.89 & 6.23 & 0.37 & 0.52 & 18.0 & 1 & - & - & 0.446 \\
\hline Lithuania & 3.11 & 5.56 & 0.52 & 0.62 & 15.1 & 1 & - & - & 0.166 \\
\hline Luxembourg & 2.25 & 2.50 & -0.09 & 0.45 & 41.8 & 2.13 & 0.38 & 0.935 & 0.312 \\
\hline Malta & 2.20 & 3.33 & -0.27 & 0.18 & 58.3 & 1 & - & - & 0.367 \\
\hline Netherlands & 1.57 & 2.71 & 0.51 & 0.52 & 22.3 & 4 & 1.34 & 3.515 & 1.897 \\
\hline Poland & 4.78 & 6.61 & 0.71 & 0.95 & 22.3 & 1 & 0.43 & 1.395 & 0.257 \\
\hline Portugal & 1.97 & 3.69 & 0.13 & 0.83 & 22.0 & 2.88 & 0.60 & 1.496 & 0.877 \\
\hline Romania & 9.94 & 10.2 & 0.91 & 0.68 & 37.0 & 2.50 & - & - & 0.262 \\
\hline Slovakia & 4.72 & 7.34 & 0.50 & 0.71 & 31.1 & 2.88 & 0.38 & 0.982 & 0.301 \\
\hline Slovenia & 5.08 & 8.48 & 0.57 & 0.87 & 40.2 & 4.06 & 0.28 & 0.713 & 0.400 \\
\hline Spain & 2.50 & 3.60 & -0.03 & 0.68 & 15.8 & 3.5 & 0.70 & 2.795 & 1.821 \\
\hline Sweden & 1.47 & 2.17 & 0.10 & 0.21 & 76.5 & 3 & 1.54 & 3.315 & 1.381 \\
\hline U.K. & 0.55 & 3.58 & 0.68 & 0.00 & 29.4 & 1 & 0.32 & 0.832 & 0.505 \\
\hline
\end{tabular}

See Data Appendix for definition of variables. $\rho()=$. correlation. 
Table 2. Base Inflation Equation

\begin{tabular}{lcccc} 
& \multicolumn{2}{c}{ Traded } & \multicolumn{2}{c}{ Non-Traded } \\
\cline { 2 - 5 } Sample & $E U 21$ & $E U 27$ & $E U 21$ & $E U 27$ \\
\hline infl $_{t-1}$ & $0.328^{* * *}$ & $0.387^{* * *}$ & $0.551^{* * *}$ & $0.476^{* * *}$ \\
u_cycle $_{t}$ & $-0.230^{* * *}$ & $-0.235^{* * *}$ & $-0.236^{* * *}$ & $-0.277^{* * *}$ \\
reer $_{t-1}$ & $-0.115^{* * *}$ & $-0.103^{* * *}$ & $-0.098^{* * *}$ & $-0.090^{* * *}$ \\
Constant & $13.75^{* * *}$ & $12.65^{* * *}$ & $10.43^{* * *}$ & $9.910^{* * *}$ \\
Fixed Effects & Yes & Yes & Yes & Yes \\
Time dummies & Yes & Yes & Yes & Yes \\
N. Obs. & 247 & 325 & 245 & 323 \\
R-squared & 0.674 & 0.736 & 0.817 & 0.802 \\
S.E. of Regression & 1.292 & 1.302 & 1.085 & 1.197 \\
\hline
\end{tabular}

Note: ${ }^{* * *}$ denotes significance at $1 \%,{ }^{* *}$ at $5 \%,{ }^{*}$ at $10 \%$

Dependent variable: for traded goods; infl $l_{T}$; for non traded: infl See Data Appendix for definition of variables. 
Table 3. The effects of labor market institutions on inflation - EU 21

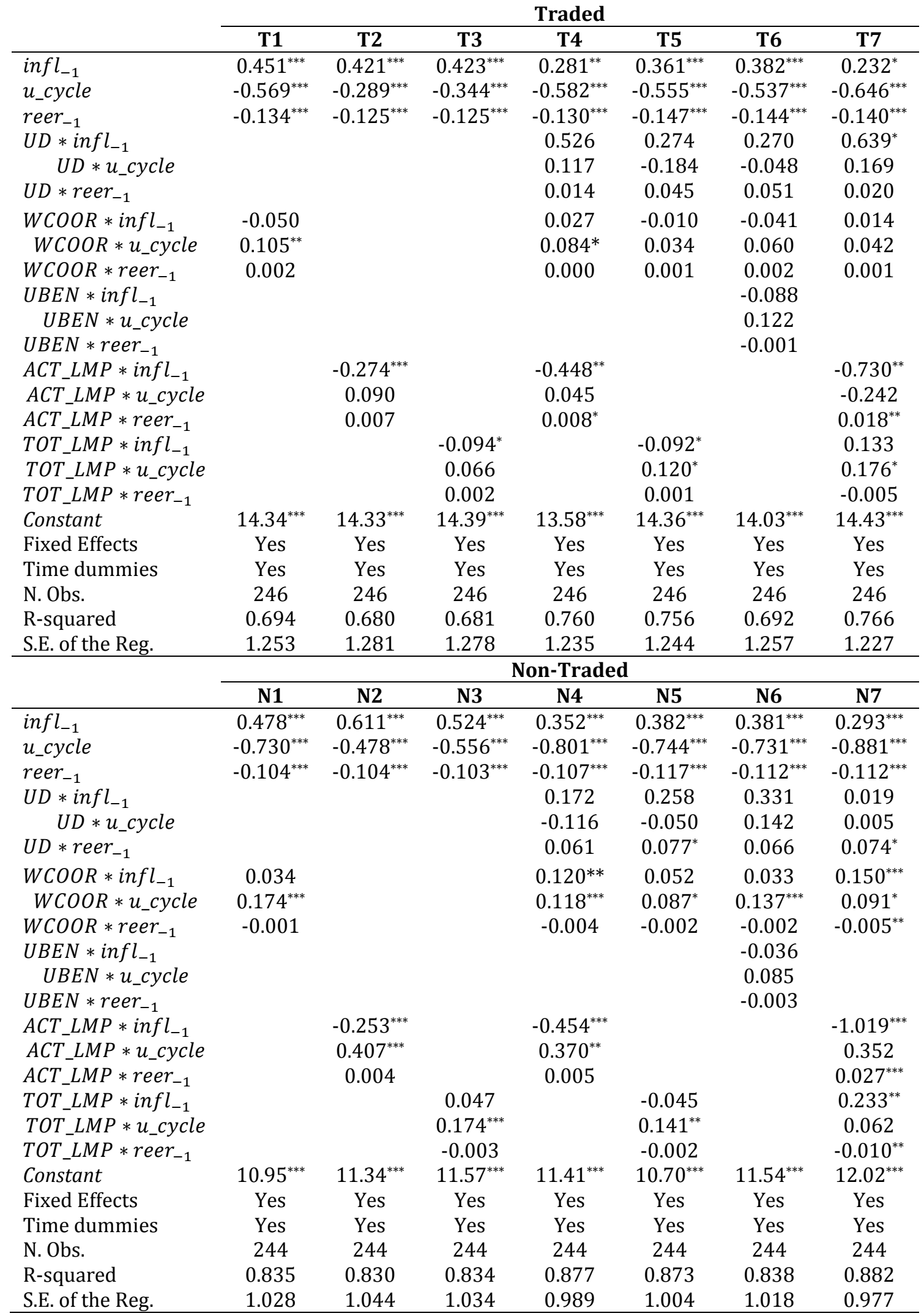

Notes: See Table 2 
Table 4. The effects of labor market institutions on inflation - EU 27

\begin{tabular}{|c|c|c|c|c|}
\hline & \multicolumn{2}{|c|}{ Traded } & \multicolumn{2}{|c|}{ Non-Traded } \\
\hline & T1 & T6 & N1 & N6 \\
\hline infl $l_{t-1}$ & $0.487^{* * *}$ & $0.531^{* * *}$ & $0.484^{* * *}$ & $0.538^{* * *}$ \\
\hline$u_{-} c_{y c l e}$ & $-0.433^{* * *}$ & $-0.440^{* * *}$ & $-0.672^{* * *}$ & $-0.655^{* * *}$ \\
\hline reer $_{t-1}$ & $-0.125^{* * *}$ & $-0.135^{* * *}$ & $-0.097^{* * *}$ & $-0.120^{* * *}$ \\
\hline$U D * \inf l_{t-1}$ & & -0.116 & & $-0.510^{* *}$ \\
\hline$U D * u_{-} c y c l e_{t}$ & & 0.033 & & 0.211 \\
\hline$U D *$ reer $_{t-1}$ & & 0.034 & & $0.099 * * *$ \\
\hline$W C O O R * \operatorname{infl}_{t-1}$ & -0.050 & -0.032 & 0.002 & 0.032 \\
\hline$W C O O R * u_{-} c^{c y c l e} e_{t}$ & $0.072^{* *}$ & 0.052 & $0.166^{* * *}$ & $0.134^{* * *}$ \\
\hline WCOOR $*$ reer $_{t-1}$ & 0.003 & 0.002 & 0.000 & -0.003 \\
\hline$U B E N * \inf l_{t-1}$ & & -0.099 & & 0.046 \\
\hline$U B E N * u_{-} c y c l e_{t}$ & & 0.057 & & 0.015 \\
\hline$U B E N *$ reer $_{t-1}$ & & -0.000 & & $-0.008^{*}$ \\
\hline Constant & $13.36^{* * *}$ & $13.42^{* * *}$ & $12.40^{* * *}$ & $11.99^{* * *}$ \\
\hline Fixed Effects & Yes & Yes & Yes & Yes \\
\hline Time Dummies & Yes & Yes & Yes & Yes \\
\hline N. Obs. & 324 & 324 & 322 & 323 \\
\hline R-squared & 0.749 & 0.747 & 0.822 & 0.843 \\
\hline S.E. of the Reg. & 1.271 & 1.277 & 1.133 & 1.063 \\
\hline
\end{tabular}

Notes: See Table 2. 
Table 5. Selected reduced models of inflation adjustment

EU 21

EU 27

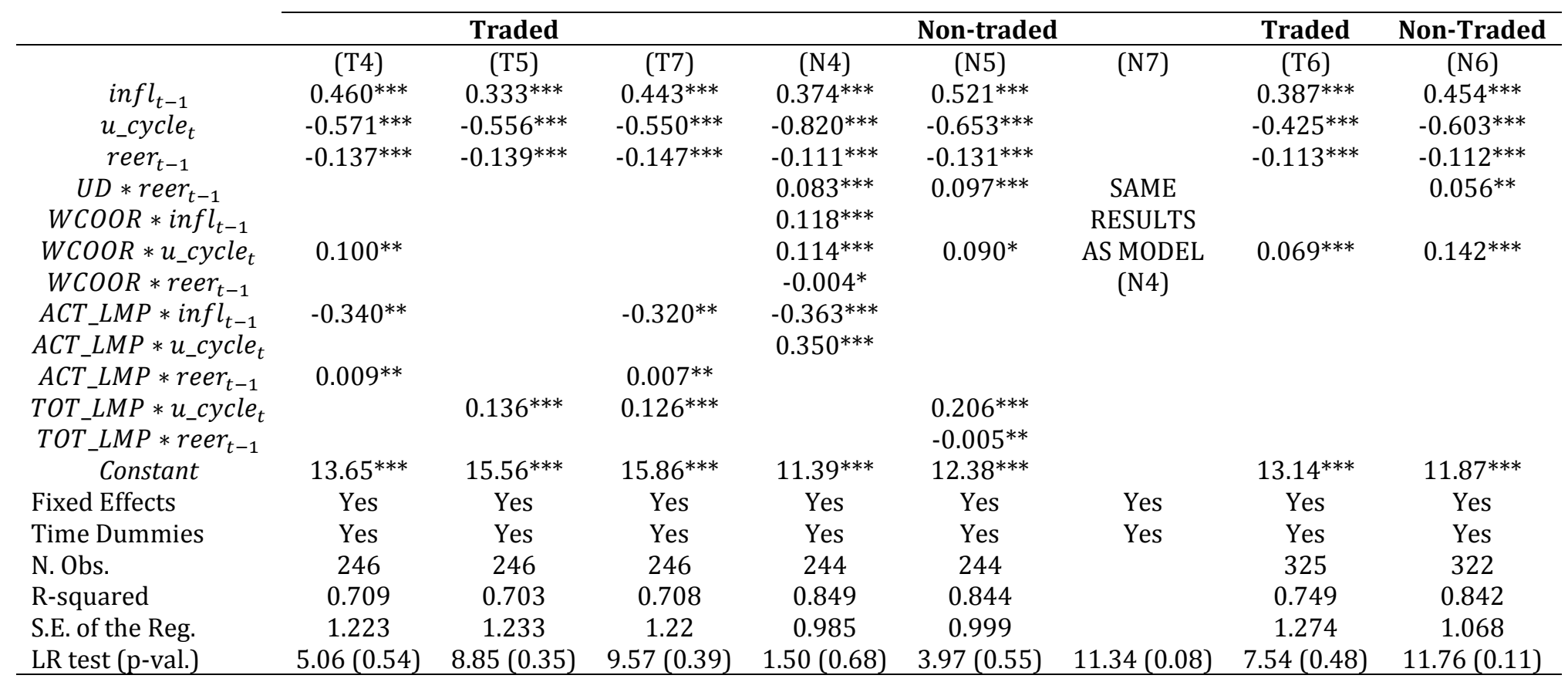

Notes: See Table 2. 
Figure 1. Traded and non-traded goods inflation 1994-2010

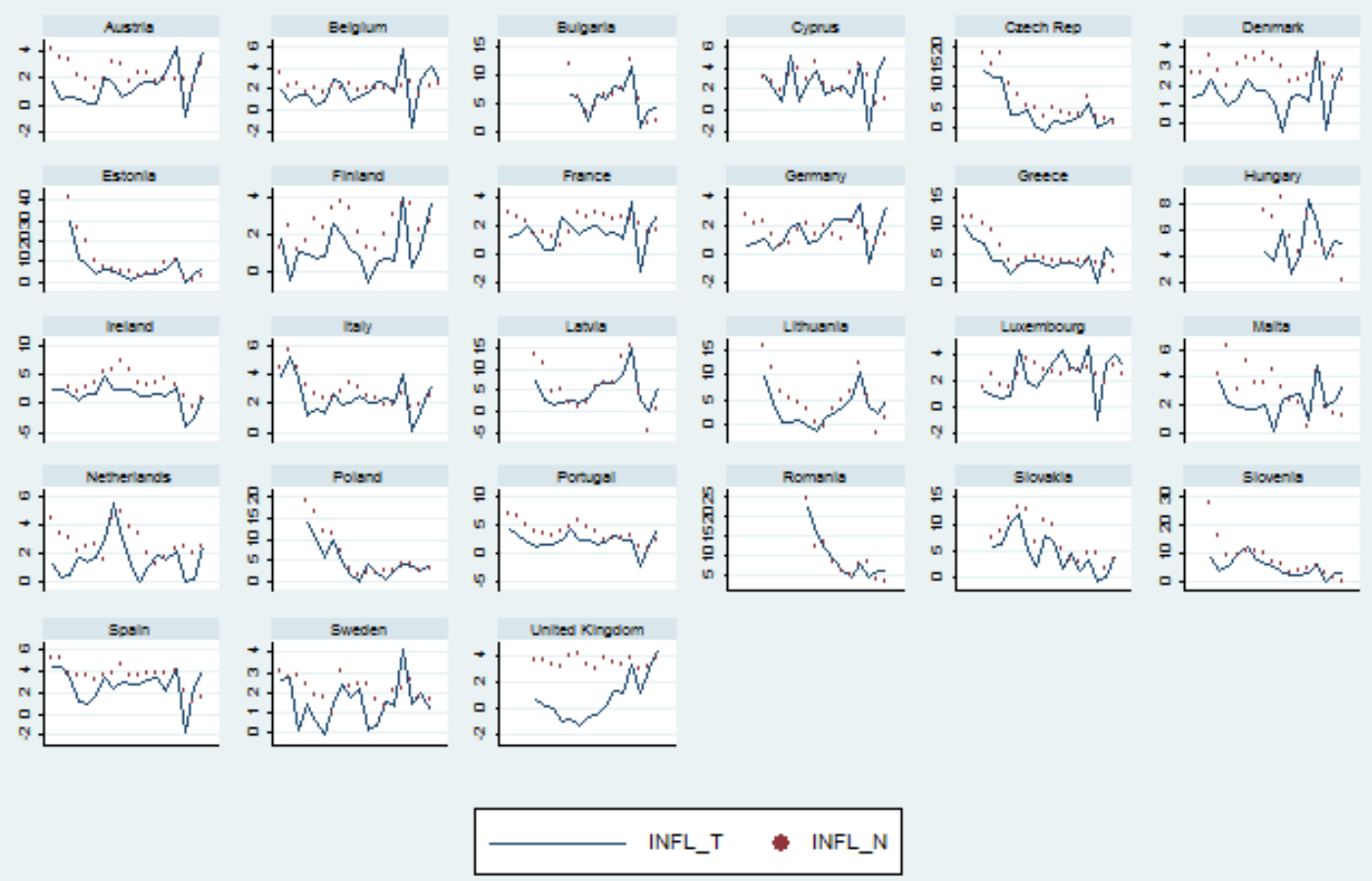

Source: Eurostat. 
Figure 2. Inflation adjustment by country
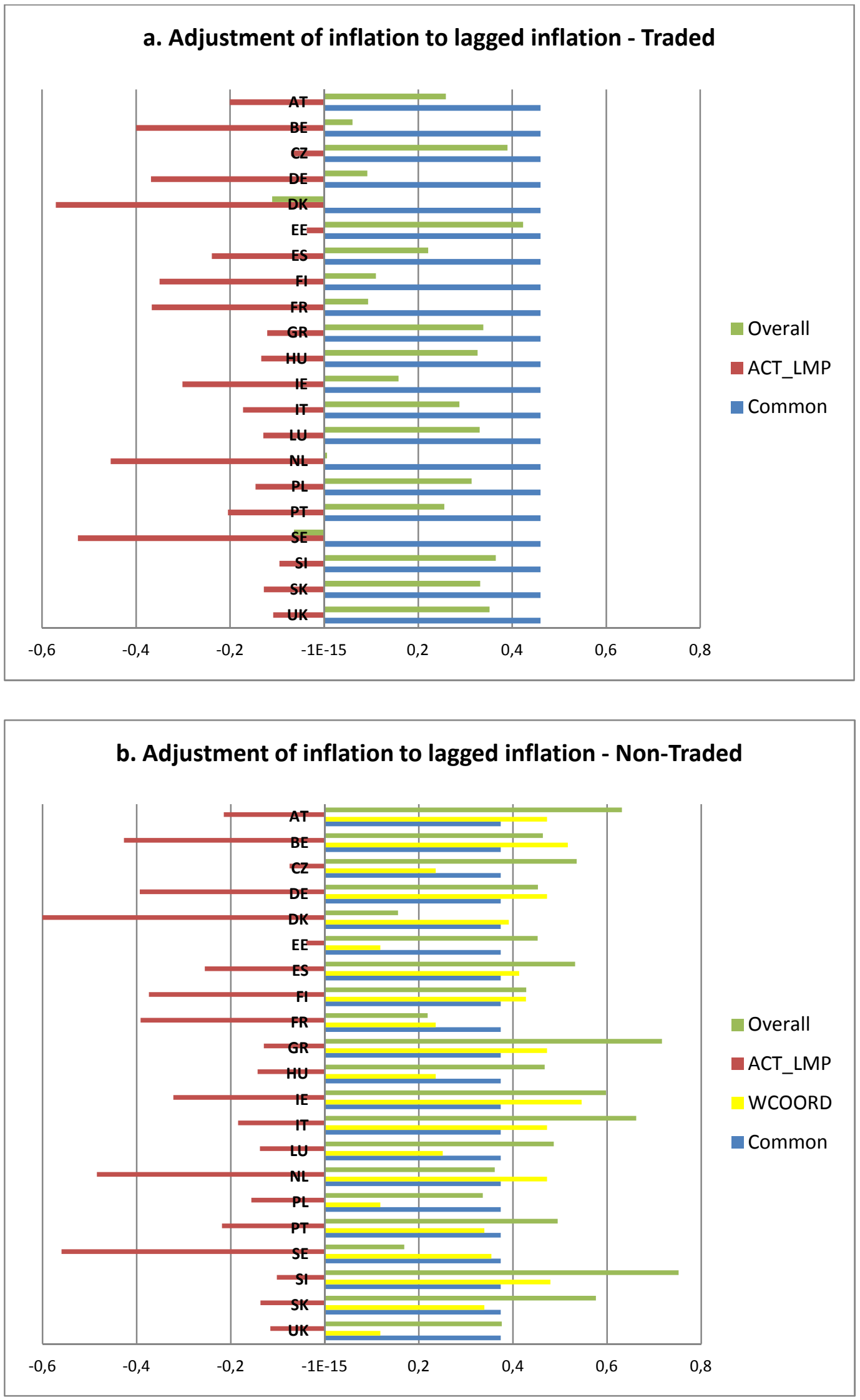

Note. In each panel, the "Common" bar and the individual country effects are computed from the point estimates in Table 5, column T4 (Traded) and N4 (Non-Traded). 

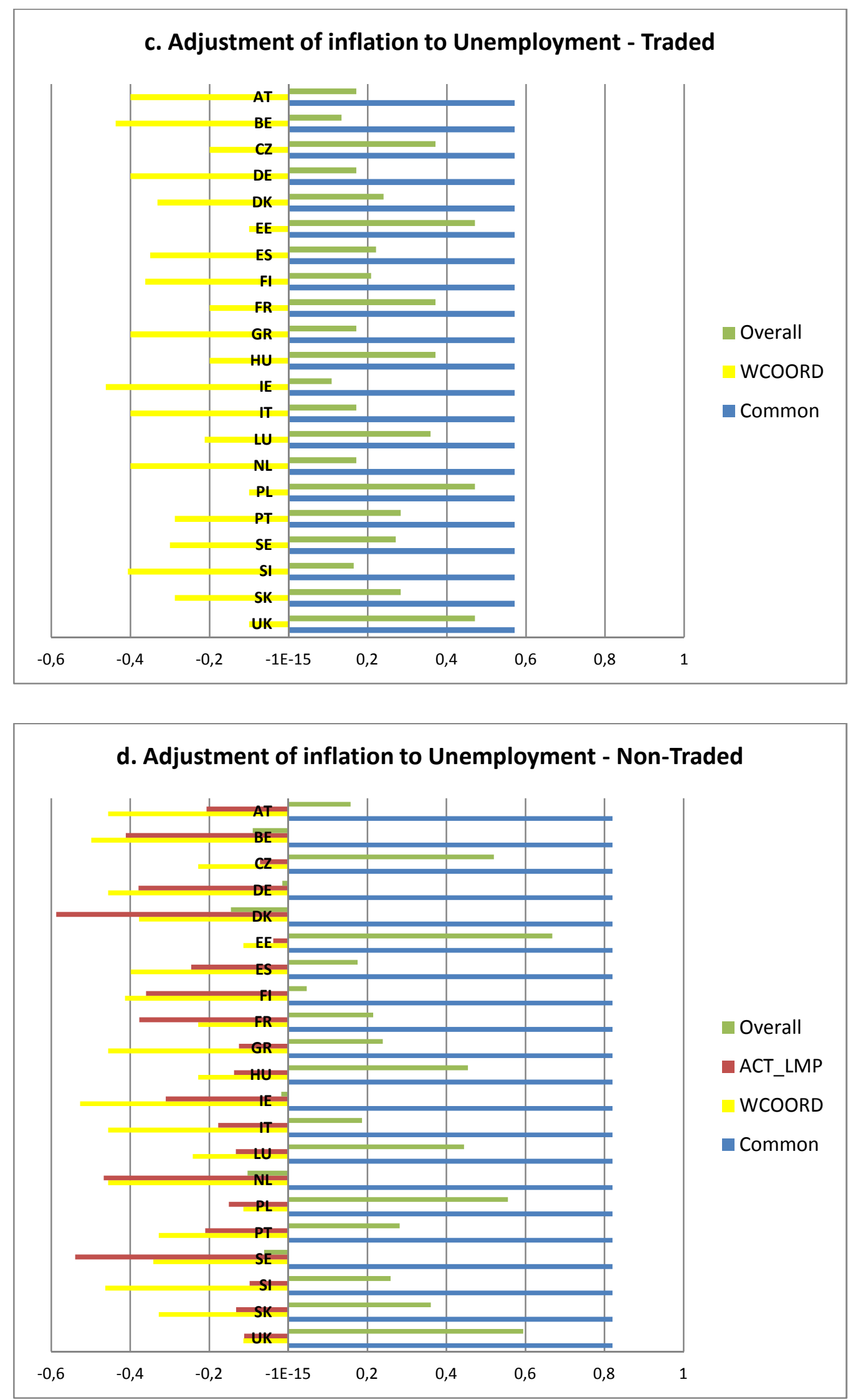


\section{e. Adjustment of inflation to REER - Traded}
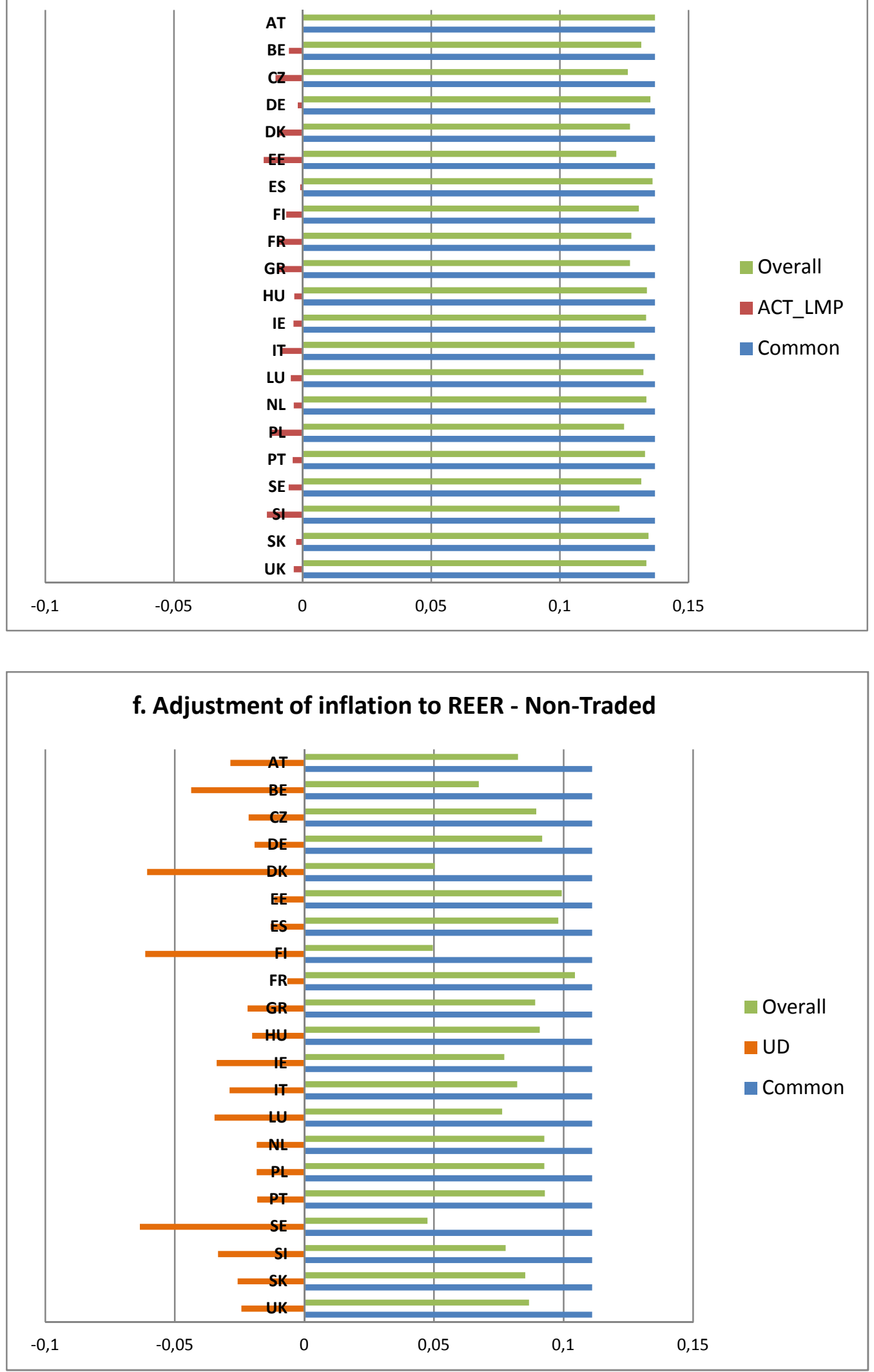